International Journal of Engineering \& Technology, $7(4.34)(2018) 217-219$
SPC
Website: $w w w . s c i e n c e p u b c o . c o m / i n d e x . p h p / I J E T$
Research paper

\title{
Towards Sustainable Development: Indonesia Project-Based Sukuk for Infrastructure
}

\author{
Nila Dewi*, Yati Mulyati, Yoga Tantular, Dudi Abdulhadi, Islahuzzaman \\ Widyatama University, Bandung, Indonesia \\ *Corresponding author E-mail: Nila.dewi@widyatama.ac.id
}

\begin{abstract}
Indonesia's economy the last few years has showed a good performance, although faced with the challenges of the global economy. However, the achievement of economic growth still has not been accompanied by equalization and adequate infrastructure. Infrastructure has an important role in supporting economic growth and thereby promotes to the reduction of economic disparity and poverty. Greater access of the poor to education and health services, water sanitation, employment, credit and markets produce is needed for creating sustainable and socially inclusive development. Recent innovation in project financing schemes to accelerate the provision of infrastructure is the implementation of sharia compliant financing. The issuance of Project Based Sukuk as an instrument for infrastructure financing has potential to enhance sustainable development. Thus, this study aims to determine the opportunities and challenges through descriptive analysis method. The result indicates that the challenges consist of investors aspects include: lack of understanding, averse to risk, market liquidity, and supporting aspects such as innovation and regulatory framework. Short term and long term strategies are applied including fundamental, technical, and roadmap strategy which are expected for the implementation of project-based sukuk in the future.
\end{abstract}

Keywords: sustainable development; infrastructure; sukuk.

\section{Introduction}

Development of infrastructure is an important goal considering its role and contribution to the growth in the economic, educational, agricultural, social, cultural and other sectors as the provision of basic needs for the life of the community. Indonesia is currently still faced with the macro problem which there is still high income inequity. In this case, the implementation of policy in the form of an active role of the government together with the private sector and the community is very much needed, one of which is through sustainable infrastructure development program. But, the logistics performance index of Indonesia is still fall behind even in ASEAN region [10]. Based on the World Bank survey, logistics performance index of Indonesia in 2016 ranked $63^{\text {rd }}$ from 160 countries. In the index, Indonesia has small score in two components, namely the low infrastructure development.

One of the government's role in facilitating and supporting the growth of infrastructure is by allocating budget mainly for the construction and maintenance of basic infrastructure. As for the relation with the era of globalization, the development of infrastructure has a key role in supporting economic growth and development as well as global competition [8]. Infrastructure plays an important role in improving the social quality while reducing inequality / disparity, poverty, and barriers to economic growth Therefore, one of the main pillars that can support the successful development of infrastructure is the funding strategy.

The development of the Islamic finance industry also responded to request for Sharia-compliant investment instrument namely sukuk, which has different structure than conventional models [2]. Islamic financial industry is able to offer systems and tools that support economic and social justice as well as stimulate economic development [3]. In Tunisia, sukuk has been instrumental in helping the government budget deficit while increasing financing for infrastructure development.

As an alternative source of infrastructure financing, since the year 2013 as the country is predominantly Muslim Indonesian government has started issuing Government Sukuk for project financing. The projects coverage among others in the form of infrastructure development (energy, telecommunications, transportation, agriculture, manufacturing and housing), public services provision, and local industry empowerment. Nevertheless, there are still challenges and obstacles in its implementation that must be faced in the utilization of sukuk as a source of infrastructure financing. Therefore, this study will describe the challenges and prospects of project-based sukuk in order to achieve sustainable development.

\section{Literature Review}

\subsection{Sustainable Development}

Sustainable development is a process that occurs within a specified period which aims to achieve sustainability. By definition, sustainable development is a process where the whole community realize their potential and strive to develop the quality of life together by utilizing the existing system order.

In this case, the important thing is how well existing policies ensure everyone has the opportunity to use the existing potential and get a good quality of life, so as to create justice and equitable development. In other words, if the development can be attributed to how to create sustainable conditions there must be an aspect of economic, social, and environmental integrated with each other [5] Sustainable development is a long-term goal which integrate the needs of local and global communities. Economic and social environment basically cannot be separated from one another. But, 
sustainable development is often perceived as a complex issue, which are faced with demands to establish consistency with thorough coverage. Further focus on various aspects including the agricultural, ecological, and economic development. All that would involve all stakeholders and the role of the nation's government.

\subsection{Implementation of Project-Based Sukuk}

Sukuk Negara, in Indonesian Sovereign Sukuk Law terminology called SBSN, is sovereign securities based on sharia principles issued by Indonesian government either Indonesian Rupiah or foreign currencies denominated. The objective of such issuances is to issue sharia-compliant securities in order to finance Indonesian National Budget. The law 19/2008 on Sovereign Shari 'ah Securities (Sukuk) contains some of the following:

a. Regulate the governance of Sukuk Negara issuance by the Central Government

b. Sukuk Negara issuance:

- Provide mandate to the government for issuing Sukuk Negara

- Establishment of the Special Purpose Vehicle

- Utilize state-owned assets and government projects as underlying

The government's aim to use other instruments in supporting development financing and help the budget deficit, among others:

a. As diversification of nation's financing sources

b. Efforts to develop alternative investment instruments

c. To finance government infrastructure projects through sukuk

d. Broaden the investor base

e. Maximizing utilization of State Owned Assets

f. Encourage Islamic Financial Market

\section{Results and Discussion}

The need for adequate infrastructure is also motivated by the increase in urbanization in the last 5 years, at $53 \%$ and expected to rise to $65 \%$ in 2025 . The conditions subsequently affect production and consumption patterns of society, in which the infrastructure is certainly playing an important role in supporting the distribution process of goods and services [7]. So, then project based sukuk start to be implemented as a step to expand and as diversification of sources of infrastructure financing.

In order to increase the allocation of infrastructure expenditure, the government promoted the pattern of public-private. The infrastructure targets which are of public services nature such as roads, bridges, and schools are under the responsibility of the government, while projects that have a high economic value such as toll roads, are undertaken by the private sector.

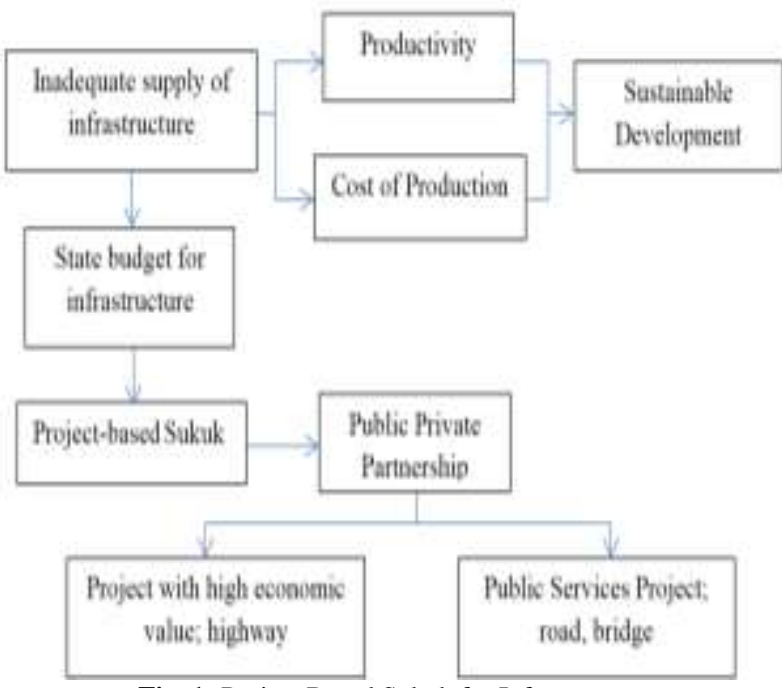

Fig. 1: Project Based Sukuk for Infrastructure
With the existence of alternative sources of financing through project-based sukuk, it is expected to resolve the problem of limited means of critical infrastructure to support the real sector. On the micro level, the inefficiency of industrial production cost can be reduced and national productivity can be increased so as to contribute to the growth target. The level of productivity, in turn, sets the level of prosperity that can be reached by an economy. The productivity level also determines the rates of return obtained by investments in an economy, which in turn are the fundamental drivers of its growth rates. At present, the mechanisms for projectbased sukuk can be done by using government projects listed in the national budget (APBN) as the underlying asset. Second, it can also be done through the initiation or submission from ministries or agencies after being proposed to Bappenas (National Development Planning Agency). Although the implementation of the project based sukuk issuance has been done, in fact there are still challenges and obstacles they faced including:

\subsection{Lack of commitment, knowledge and understanding, averse to risk, and floating majority}

Lack of commitment, knowledge and understanding, averse to risk, and floating majority is the lack of commitment and knowledge held by the investor. In this case, investors do not know the characteristics and advantages of the sukuk. Investors are also faced with the risk of liquidity in the secondary market whose growth is tend to be slow [4]. Sukuk is also basically had the opportunity of a broader scope of investors both Islamic and conventional investors, from banks, insurance companies, pension funds, mutual funds, and SOEs. However, in reality sukuk is dominantly absorbed by conventional insurance and Islamic banking. In addition investors tend to be conservative by choosing which is more profitable without seeing and considering aspects of sharia. Investors will be interested in buying sukuk if it is considered capable of providing higher yields than conventional instruments.

\subsection{Incentive, taxation, socialization, understanding of underwriter}

Incentive, taxation, socialization, understanding of underwriter, namely the lack of government incentives. Government is expected to provide special treatment for encouraging the development of the sukuk market by incentives. Clarity of tax regulation; tax laws become important elements that determine interest in the sukuk instrument. Although some experts have been assessing tax issues can be resolved, but some judged that there is no specific standard provisions. Lack of socialization also remains a necessity agenda because the lack of administration knowledge for the public specifically regarding Islamic capital market instruments i.e. sukuk. Thus, it contributes too many market participants who do not know clearly the characteristics and applications of sources of funding through sukuk. Currently, underwriters which are active and understand sukuk issuance remains limited.

\subsection{Lack of instruments, low of size of issuance, liquidi- ty of secondary market}

Currently, sukuk still has limitations in terms of the type of contract and the period (tenor). Sukuk which has been recently applied consists from sukuk Ijarah scheme for project-based sukuk, or mudaraba. Value issuance or lower emissions, which is not in accordance with the demand of investors; on market conditions, there is often an imbalance between demand and supply where the number of existing supply is unable to meet the investor's needs or can be said to be limited. The next major issue is the conditions in the secondary market is less liquid.

To support the success of the sukuk market, Indonesia should be more directed to the variation of sukuk structure itself. Sukuk issuance should be appropriate and based on the objectives of sharia namely social welfare [9]. As for the alternative solution could be found, among others: 
a. Fundamental

1.) Formal education; 2.) Conducting intensive, focused and integrated socialization; 3.) Optimizing Good Corporate Governance in an effort to increase corporation performance; 4.) Improving and enhancing the role of profession and supporting institutions and formulating standard operating guidelines;

b. Technical

1.) Product innovation in terms of the type of contract and period; 2.) Provision of incentives for issuers and investors; 3 .) Marketing, especially promotional activities; 4.) Training programs (training, workshops) by the government, private sector or associations.

c. Macro strategy

Improving domestic investor base and open the market to foreign investors, especially investors from the Middle East that is specifically concerned with sharia-compliant investment; 2.) Providing education and specialized training for the underwriter; 4.) The application of directed market driven, a strategy following the market by directing indirectly towards the desired direction.

d. Roadmap

Completion of the regulation; taxation and standard guidelines of publishing mechanism, 2) Preparation of the grand design of educational and promotional patterns by [4] or OJK in collaboration with the actors and the association as a common reference, 3) Promoting the development of human resources for competence, experience, and moral through the application of qualification and certification standards for professionals, 4) The convergence of sharia-compliance and global best practice, the alignment and harmonization of the international infrastructure such as Accounting and Auditing of International Financial Institution (AAOIFI) [1], International Islamic Financial Market (IIFM) and International Financial Sharia Board (IFSB) [6].

\section{Conclusion}

Based on the description above, it can be concluded that the problems faced by Indonesia related to the lack of investment in infrastructure is something which is of critical concern. With the structural movement from the primary sector to the manufacturing and service sectors, infrastructure and connectivity become the main focus of national development strategies and to accelerate economic growth. Islamic financing has great potential to provide an alternative solution for infrastructure financing. Sources of financing through project-based Sukuk become a reliable alternative instrument to help finance government projects listed in the national budget. However, there are also obstacles and constraints encountered, both from the market and macro-economic conditions. So, we need a strategy of sustainable development, especially related to the government's commitment, effective coordination among economic actors, product innovation, and intensive socialization.

\section{References}

[1] Accounting and Auditing Organization for Islamic Financial Institutions (AAOIFI). 2008. Ruling on Sukuk. Working Group: Bahrain.

[2] Ahmad, Wahida and Rafisah Mat Radzi. Sustainability of Sukuk and Conventional Bond During Financial Crisis: Malaysia's Capita Market. Global Economy and Finance Journal Vol.4 No.2 September 2011. Pp.33-45.

[3] Araar, Mohamed. Islamic Finance Based on Sukuk Approach: The Roadmap for Economic Development in Tunisia. Journal of Islamic banking and Finance March 2014, Vol. 2, No.1,pp. 197-208 ISSN: 2374-2666.

[4] Bapepam LK (Capital Market Supervisory Agency and Financial Institution). 2010. Study of Product Development of Islamic
Capital Market (Sukuk Musyarakah and Sukuk Istishna). Indonesia Ministry of Finance.

[5] Gilmour, Daniel. et al. 2011. Sustainable Development Indicators for Major Infrastructure Projects. Municipal Engineer Volume 164 Issue ME1 pg.15-24.

[6] Islamic Financial Services Board, 2009. Capital Adequacy Requirements for Sukuk Securitisations and Real Estate Investment

[7] Ministry of Finance, Indonesia. 2016. Sukuk for Infrastructure Development: Indonesia Experience. $1^{\text {st }}$ Annual Islamic Finance Conference: Jakarta.

[8] Mutamba, Jeremiah. 2015. Approaches to Infrastructure Planning and Roll-Out: A Comparative Analysis. International Journal of Arts and Science ISSN: 1944-6934, 08 (04): pg.527-536.

[9] Shafi, Roslina Mohamad and Mohd Asyadi Redzuan. Modelling Sukuk Structures in Indonesia: Economic Development and the Risk Management.

[10] World Economic Forum. 2016. The Global Competitiveness Report 2016-2017. Insight Report, Geneva. 